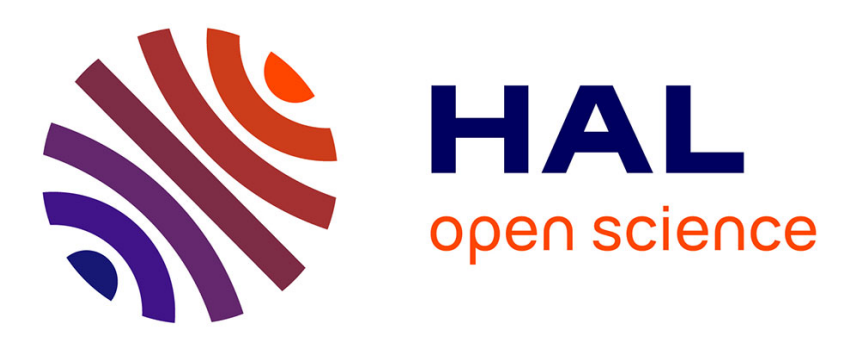

\title{
Exploring prosumption: Reconfiguring labor through rural-urban food networks?
}

Antonello Podda, Allison Loconto, Davide Arcidiacono, Lara Maestriprieti

\section{To cite this version:}

Antonello Podda, Allison Loconto, Davide Arcidiacono, Lara Maestriprieti. Exploring prosumption: Reconfiguring labor through rural-urban food networks?. Journal of Rural Studies, 2021, 82, pp.442 - 446. 10.1016/j.jrurstud.2020.12.005 . hal-03173158

\section{HAL Id: hal-03173158 https://hal.inrae.fr/hal-03173158}

Submitted on 18 Mar 2021

HAL is a multi-disciplinary open access archive for the deposit and dissemination of scientific research documents, whether they are published or not. The documents may come from teaching and research institutions in France or abroad, or from public or private research centers.
L'archive ouverte pluridisciplinaire HAL, est destinée au dépôt et à la diffusion de documents scientifiques de niveau recherche, publiés ou non, émanant des établissements d'enseignement et de recherche français ou étrangers, des laboratoires publics ou privés.

$$
\text { Copyright }
$$


Editorial

Exploring prosumption: Reconfiguring labor through rural-urban food networks?

\section{A B S T R A C T}

The aim of this special issue is to explore emergent phenomena in the agri-food sector through the lens of prosumption, in order to highlight its heuristic value in identifying new and emerging trends in the field, especially focusing on the interplay between social and economic relations. This introduction explores the theoretical foundations of the notion of prosumption and the linkages with the alternative agri-food networks literature in order to propose a new set of research questions that can help scholars to better articulate the relationships between the emergence of hybrid actors and new forms of work in the production and consumption of food.

When, in 1986, Carlo Petrini proposed a vision of a food system based on 'prosumption' (Petrini, 2003) - where consumers 'co-produce' the food that they eat - this concept required a leap of faith by both producers and consumers who were still working within a 'marketness' mindset (Hinrichs, 2000). Since these early studies, however, we have seen the emergence of numerous forms of direct sales and networked market engagement between producers and consumers that have extended the embeddedness arguments to bring more nuance into the diversity of political, social and economic relations in food consumption and production (Goodman et al., 2012). This is demonstrated by the global expansion of the community supported agriculture (CSA) movement that now counts initiatives on 5 continents; the re-emergence of farmers' and weekly markets that offer direct interaction between producers and consumers; and the development of e-platforms for food (e. g., food assemblies) that create this link virtually. During the COVID-19 pandemic, these solidarity-based food exchanges reported increases in both the number of people purchasing through existing intiatives and the emergence of new initiatives around the globe (FAO, 2020). For example in France, a national level technical network followed the changes in food provisioning throughout the crisis period and found that existing initiatives consolidated their client base, particularly when there was a personalised service linking producers and consumers, but new initiatives faced difficulties in customer loyalty because they hadn't invested in building strong producer-consumer relationships before the social distancing requirements came into effect (Marechal, 2020). Inherent in these movements is thus the open question as to the reorganisation of the roles of producers and consumers and the divisions of labour that emerge to enable loyal exchange relationships within food systems.

\section{Prosumption and alternative agri-food networks, a rose by any other name?}

Petrini's use of the word 'prosumer' is the translation of a concept developed originally in the high-tech, dotcom industry. The development of information and communication technology (ICT) is one of the crucial drivers in a process of transforming users from simple consumers into producers of information and content. Barnard (1938) was one of the first scholars to refer to consumers as "almost-employed" and over twenty years ago other scholars identified a growing consumer involvement in the co-construction of the consumer experience via the concept of servuction (Langeard and Eiglier, 1997). Even as far back as the 1960s, during the era of unions and workers movements, Fuchs and Leveson (1968) showed that the consumer could be treated as a factor of production similar to waged labour. However, following the oil crisis of the 1970s and the progressive introduction of neoliberal economic policies focused on increasing consumption, Toffler (1970) started to speak about prosumers, while Bruns (2008) spoke about the rise of prousage or ProAMs (professional amateurs) to refer to produce for use instead of production for exchange.

The popularity of the term 'prosumer' in the social sciences is linked to the work of Ritzer (2014), who uses the term to describe "a process that 'subsumes production and consumption' and characterises every human activity” (Dusi, 2018, p. 4, p. 4). Ritzer's argument was that the separation of prosumption into the two distinct concepts of production and consumption was simply a bias of the historical constructions that separated labor from the means of production and created the consumer as a product of capitalism. While both schools are techno-determinist, Toffler saw prosumption as the emancipation of the consumer in the 'do it yourself' movement (cf. Watson and Shove, 2008), while Ritzer's vision saw prosuming machines replacing humans in both the production spheres like factories and in the consumption spheres like nano-sensors on food that tell us if the food is expired. In both scenarios, the fine line between production and consumption is seen more as a continuum of practices than a tipping point.

In the sociology of agriculture and food, the experiences of alternative agri-food networks (AFN) were also developing the concept of prosumers where consumers were taking on more productive activites in 
food systems, particularly in relation to their own use of these service (Barbera and Dagnes, 2016; Grasseni, 2013). Specifically, geography-inspired analyses identified short food supply chains and relocalisation initiatives that sought to close physical, relational and temporal distance between producers and consumers (Goodman et al., 2012; Renting et al., 2003). In OECD countries, AFNs emerged often as a response to the ever-increasing contradictions of the globalised, unsustainable industrial food system and actors used the discourse of quality to relocalise consumption patterns (Winter, 2003). In these experiences we find consumers who refuse to have a purely passive role in the agri-food chain and who are looking for different value and meanings in how food reaches their tables (Ostrom et al., 2017). By focusing on their ethical and social goals and on the fact that consumers are often citizens, civic food networks (Renting et al., 2012) can be discussed, in which citizen-consumers (Johnston, 2008; Zamagni, 2003) are committed to socially responsible choices and want to create further demand that also takes into account their ethical values (Carrera, 2009).

In this literature, the "consumer" is a fundamental actor in food production and the organisation of its work: particularly the processing, transporting, preparing and eventually eating of it as part of meaningmaking socio-cultural practices. Often, the middle ground between production and consumption takes place outside of the "formal economy" in the "substantial economies" (Polanyi, 1957) or "diverse economies" (Gibson-Graham, 2008) where enterprise, labour, property, transactions, and finance are organised in alternative ways. This literature also demonstrates the fundamental role that networks of relationships have within AFNs. If the contrast between buyer and seller may work to explain the long chains dominated by market transactions and pure value extraction (Bentham et al., 2013), it certainly does not explain the behaviour of those actors who follow other objectives in food provisioning. The AFN literature clearly demonstrates that other values are exchanged when there are ethical, political, environmental or economic (e.g., fair prices and living wages) objectives to the exchange (Maestripieri, 2019; Ostrom et al., 2017). By bringing the notion of prosumption into academic debates in agrifood studies, we thus propose that there is a need to consider consumers as actors not excluded or separated from the production system. Rather, they are concrete generators of content, products and services in market exchanges, which can have both negative and positive effects for the quantity and type of work they do in agri-food systems.

The aim of this special issue is to explore emergent phenomena in the agri-food sector through the lens of prosumption, in order to highlight its heuristic value in identifying new and emerging trends in the field, especially focusing on the interplay between social and economic relations. Glucksmann's $(2009,2016)$ notion of the total social organisation of labor offers an interesting framework for our purposes. Whereas the technical division of labor is the process of differentiating between formal and informal activities, paid or unpaid, traditional or technically specialised; the total social organisation of labor, suggests that every task can be achieved in different ways by crossing different domains or institutions (market, state, community, household, etc.). The organisation or prioritisation of tasks, and thus the importance of each task, varies dynamically over time. From a neo-Polanyian perspective, we are talking about work as an instituted economic process. Consumers' actions cannot be understood except in relation to all the other forms of work undertaken in the other instituted economic processes - i.e., production, processing, distribution and exchange. Instead of money, trust becames the exchanged value on the alternative market of food prosumption. The articles brought together in this special issue analyse the role of the "prosumer" in the work required to produce not just food, but also the alternative values that are produced and consumed in agro-food systems.

\section{Exploring agri-food prosumption}

Prosumers support and embody new proposals and experiences for alternative production paradigms (Arcidiacono, 2013; Stolle et al., 2005; Willis and Schor, 2012) that are trying to re-shape global and local value chains by re-embedding and re-socialising economic exchanges. This trend deals with a re-appropriation strategy of their own market sovereignty that affects the market mechanisms characterising the nine experiences of Alternative Food Networks that are included in this special issue and summarised in Table 1.

There are three analytical dimensions that relate to prosumption emerging from the nine articles in this issue. The first one is related to the active participation of consumers and their implication in the processes of production. Prosumers are re-organising and re-scaling the production and distribution of basic goods and services that enable them to be more involved in all processes from production to consumption. This increased work acts as a strategy of "resistance" (de Certeau, 2011). In this sense, Toffler's 'production as use' vision for prosumption is part of the autonomy gained through these intiatives. Indeed, there is evidence of this in the cases presented in this Special Issue that examine the Seikatsu Club Consumer Cooperative in Japan (Hatanaka, 2020), the Co-producers of Campi Aperti in Bologna, Italy (Alberio and Moralli, this issue) and the Utopia Box-scheme in Ecuador (Castilla Carrascal, this issue). Thus, trust is rebuilt through the relationship between producers and consumers on the basis of direct or mediated interaction between the two subjects (Marsden et al., 2000).

But, as a second analytical dimension, the blurring of production and consumption could have not been possible without specific organizational forms. The cases of Solidarity Purchasing Groups in Piedmont (Barbera et al., 2020), of Community Supported Agriculture in Catalunya (Espelt, 2020) and the Nested Market in Italy (Osti and Carrosio, 2020) shows that in order to achieve fruitful and effective prosumption exchange have to be also organised in different forms, that challenge the separation between consumer and production and build up new institutions for the practices alternative to markets (Maestripieri, 2018). On the contrary, when the prosumption is based on the digitalisation of practices, such as in the case of La Ruche che dit Oui! In France (Stephens and Barbier, this issue), the risk is that the participation of consumers is erratic and superficial, while market relationships remains substantially unchallenged.

The importance of organising practices emerges also when we focus on the type of trust produced within the single cases. The more organised, formal and stable institutions are created (such as Seikatsu Club Consumer Cooperative in Japan or the CSAs in Catalunya) the more social capital is generated within the AFNs. But, how does this question of trust change if we take seriously the idea that prosumers are 'laborers' within the food system who take on new responsibilities in the production of food? The complex relationship between consumers and producers should, in theory, open up space for the creation of bottom-up social innovation (Pellicer-Sifres et al., 2017). However, very few studies have opened the black-box of the relationship between consumers and producers in order to understand if they are effective at creating new economic spaces and with them labour relations for producers and consumers (Maestripieri, 2019). The system of auditing is one of the mechanism by which social innovation can trigger new economic spaces, as demonstrated by the case of Campi aperti in Italy and the Seikatsu Club Consumer Cooperative in Japan.

Thirdly, prosumption could determine a dangerous workshift where jobs that were previously professionalised shift into labor burdens on communities or households, in order to extract value from consumers' work and transform it into a driver of exploitation (Dujarier, 2009). For example, there are documented cases of tool libraries, digital time banking, solidarity purchasing groups, ride-sharing, social eating, social streets, co-housing, social lending, and complementary currencies that have succeeded or failed based on the willingness of prosumers to contribute their uncompensated time and labor. Many of these new forms of co-production and sharing are enabled by digital platforms or by the entry of new actors into intermediary spaces. Yet these mediated relationships often seem to be less engaged politically than those direct 
Table 1

Conceptualising prosumption and trust in alternative food networks.

\begin{tabular}{|c|c|c|c|c|c|}
\hline Authors & Key research question & $\begin{array}{l}\text { Key concepts and } \\
\text { theory }\end{array}$ & Analytical approach & $\begin{array}{l}\text { Key contributions for a debate on } \\
\text { prosumption }\end{array}$ & Notion of trust \\
\hline $\begin{array}{l}\text { Filippo } \\
\text { Barbera, } \\
\text { Joselle } \\
\text { Dagnes, } \\
\text { Roberto Di } \\
\text { Monaco }\end{array}$ & $\begin{array}{l}\text { Are there different forms of } \\
\text { consumers' participation based } \\
\text { on the relationships established } \\
\text { with producers? Is the form of } \\
\text { participation affecting } \\
\text { consumers' attitudes and } \\
\text { behaviours? }\end{array}$ & $\begin{array}{l}\text { Alternative Food } \\
\text { Networks and } \\
\text { Solidarity } \\
\text { Purchasing Groups }\end{array}$ & $\begin{array}{l}\text { Semi-structured } \\
\text { questionnaire ( } 1.090 \\
\text { interviews) to participants } \\
\text { of SPGs in Piedmont } \\
\text { region, Italy. PCA and } \\
\text { regression. }\end{array}$ & $\begin{array}{l}\text { Intrinsic motivation for } \\
\text { consumption and meaning- } \\
\text { making mechanisms are } \\
\text { empirically correlated with the } \\
\text { organisational settings and the } \\
\text { type of participation in the SPGs. }\end{array}$ & $\begin{array}{l}\text { The type of participation into the } \\
\text { SPGs influence the construction } \\
\text { of meaning associated with } \\
\text { consumption: consumers } \\
\text { participate in AFNs because of } \\
\text { the peculiar type of exchange } \\
\text { they can build up with producers } \\
\text { and other SPGs members. }\end{array}$ \\
\hline Ricard Espelt & $\begin{array}{l}\text { Which type of CSA promotes } \\
\text { agroecology prosumption and } \\
\text { how is this done? }\end{array}$ & $\begin{array}{l}\text { Community } \\
\text { Supported } \\
\text { Agriculture and } \\
\text { Agroecology } \\
\text { Prosumption }\end{array}$ & $\begin{array}{l}\text { Qualitative interviews } \\
\text { with CSA members and } \\
\text { suppliers and quantitative } \\
\text { web content analysis }\end{array}$ & $\begin{array}{l}\text { Although volunteer groups are } \\
\text { the majority ( } 91,2 \% \text { of CSAs), } \\
\text { formally organised groups with } \\
\text { employees have the potential to } \\
\text { reach more consumers and to } \\
\text { have a wider impact on } \\
\text { prosumption. }\end{array}$ & $\begin{array}{l}\text { Cooperatives are better able to } \\
\text { build trust, because they have a } \\
\text { more formal and stable structure } \\
\text { compared to volunteer groups } \\
\text { and the capacity to reach a wider } \\
\text { audience of consumers. }\end{array}$ \\
\hline $\begin{array}{l}\text { Giorgio Osti } \\
\text { and } \\
\text { Giovanni } \\
\text { Carrosio }\end{array}$ & $\begin{array}{l}\text { Is the concept of nested markets } \\
\text { more able to understand } \\
\text { prosumption in marginal areas } \\
\text { compared to the centre- } \\
\text { periphery framework? }\end{array}$ & $\begin{array}{l}\text { Nested markets } \\
\text { and rural marginal } \\
\text { areas }\end{array}$ & $\begin{array}{l}\text { Secondary analysis of a } \\
\text { purposive small sample of } \\
\text { seven Italian cases of } \\
\text { nested markets. }\end{array}$ & $\begin{array}{l}\text { Nested markets are organised } \\
\text { fields in which consumers and } \\
\text { producers can orient their } \\
\text { behaviors according to } \\
\text { normative, identity, and } \\
\text { solidarity aspects. }\end{array}$ & $\begin{array}{l}\text { The transformative capacity of } \\
\text { nested markets in rural areas lies } \\
\text { in generating trusted } \\
\text { relationships between producers } \\
\text { and consumers. }\end{array}$ \\
\hline $\begin{array}{l}\text { Tatiana } \\
\text { Carrascal }\end{array}$ & $\begin{array}{l}\text { What is the role of Utopia } \\
\text { Basket's consumers in the } \\
\text { organisation of intercultural } \\
\text { solidarity circuits }\end{array}$ & $\begin{array}{l}\text { Alternative Food } \\
\text { Networks and } \\
\text { Intercultural } \\
\text { Economic Circuits }\end{array}$ & $\begin{array}{l}\text { Document analysis, } \\
\text { participant observation } \\
\text { and in-depth interviews }\end{array}$ & $\begin{array}{l}\text { The active participation of } \\
\text { consumers is fundamental in } \\
\text { setting up the intercultural } \\
\text { economic circuits on which the } \\
\text { Utopia Basket is based. }\end{array}$ & $\begin{array}{l}\text { Challenging elitism that } \\
\text { characterise AFNs experience in } \\
\text { high-income countries, } \\
\text { consumers of the Utopia Box- } \\
\text { scheme are actually creating } \\
\text { bonds that cross ethnic and class } \\
\text { divisions. }\end{array}$ \\
\hline $\begin{array}{l}\text { Maki } \\
\text { Hatanaka }\end{array}$ & $\begin{array}{l}\text { Can the organizational structure } \\
\text { of an AFN favor the } \\
\text { establishment of food citizenship } \\
\text { among its members? How do } \\
\text { food citizens engage in } \\
\text { governance and what kind of } \\
\text { governance processes enable } \\
\text { people to act as food citizens? }\end{array}$ & $\begin{array}{l}\text { Ethical } \\
\text { consumerism and } \\
\text { Food citizenship }\end{array}$ & $\begin{array}{l}\text { Two rounds of semi- } \\
\text { structured interviews, first } \\
\text { in } 2008 \text { and then in } \\
2014-2015 \text {. }\end{array}$ & $\begin{array}{l}\text { Participation implies going } \\
\text { beyond ethical consumerism and } \\
\text { constitutes an example of food } \\
\text { citizenship based on } \\
\text { prosumption. Active members } \\
\text { (consumers and producers) } \\
\text { engage in defining sustainability } \\
\text { standards, by the audit-by-many } \\
\text { mechanism and sharing risk and } \\
\text { responsibilities thanks to strong } \\
\text { partnerships. }\end{array}$ & $\begin{array}{l}\text { The audit labor that prosumers } \\
\text { assume in Japan achieve a } \\
\text { horizontal and equal partnership } \\
\text { between producers and } \\
\text { consumers, overcoming the } \\
\text { disconnection of the two groups. }\end{array}$ \\
\hline $\begin{array}{l}\text { Marco Alberio } \\
\text { and Melissa } \\
\text { Moralli }\end{array}$ & $\begin{array}{l}\text { Are co-producers involved in the } \\
\text { production process? Which are } \\
\text { the dynamics generated by the } \\
\text { consumer-producer relation? Can } \\
\text { co-producers be considered } \\
\text { prosumers, or do they represent } \\
\text { an independent and new } \\
\text { typology of consumers? }\end{array}$ & $\begin{array}{l}\text { Prosumption and } \\
\text { Hibridity }\end{array}$ & $\begin{array}{l}\text { In-depth interviews with } \\
\text { producers and participant } \\
\text { observations during the } \\
\text { market days }\end{array}$ & $\begin{array}{l}\text { Prosumption stems from the } \\
\text { blurring of the social and the } \\
\text { economic in relationships } \\
\text { between consumers and } \\
\text { producers, via the audit-by-many } \\
\text { mechanism defined by the } \\
\text { Participatory Guarantee System. }\end{array}$ & $\begin{array}{l}\text { The active participation of } \\
\text { consumers in auditing becomes } \\
\text { the way by which AFNs create } \\
\text { new economic relationships, } \\
\text { going beyond market relations. }\end{array}$ \\
\hline $\begin{array}{l}\text { Paulo } \\
\text { Niederle }\end{array}$ & $\begin{array}{l}\text { How does veganism contribute to } \\
\text { Sustainable Food Systems? }\end{array}$ & Practice theory & $\begin{array}{l}\text { In-depth interviews with } \\
\text { managers and chefs, } \\
\text { observations and } \\
\text { questionnaires to } \\
\text { consumers of vegan } \\
\text { restaurants }\end{array}$ & $\begin{array}{l}\text { Although veganism is only } \\
\text { partially associated with the } \\
\text { promotion of sustainable food } \\
\text { practices, restaurants and } \\
\text { consumers do promote the } \\
\text { consumption of locally produced } \\
\text { food. Only a minority of } \\
\text { restaurants produce their own } \\
\text { food. }\end{array}$ & $\begin{array}{l}\text { A closer analysis of sustainable } \\
\text { practices shows that they can be } \\
\text { the base for promoting the } \\
\text { creation of stronger relationships } \\
\text { between vegan and vegetarian } \\
\text { communities and local food } \\
\text { producers. }\end{array}$ \\
\hline $\begin{array}{l}\text { Rafaël } \\
\text { Stephens } \\
\text { and Marc } \\
\text { Barbier }\end{array}$ & $\begin{array}{l}\text { How relevant is prosumption in } \\
\text { dealing with alternative agrifood } \\
\text { systems, and in enriching } \\
\text { sociological debates around food } \\
\text { production, distribution, and } \\
\text { consumption? }\end{array}$ & $\begin{array}{l}\text { Prosumption and } \\
\text { Alternative Food } \\
\text { Network }\end{array}$ & $\begin{array}{l}\text { Structured interviews with } \\
\text { members of "La Ruche qui } \\
\text { dit Oui" and secondary } \\
\text { analysis of food } \\
\text { presentations in the } \\
\text { website }\end{array}$ & $\begin{array}{l}\text { Producers and suppliers co- } \\
\text { construct meanings and discourse } \\
\text { on food using the platform } \\
\text { provided, which is digital and } \\
\text { ephemeral at the same time. } \\
\text { Participation and membership is } \\
\text { liquid and unstable, but } \\
\text { discourses are persistent. }\end{array}$ & $\begin{array}{l}\text { This case challenges the } \\
\text { assumption by which the digital } \\
\text { reputation ratings could push } \\
\text { towards a more 'ethical' and } \\
\text { consumer/society driven } \\
\text { economy). Participation is liquid } \\
\text { and unstable when digitally } \\
\text { mediated. }\end{array}$ \\
\hline
\end{tabular}

relationships noted in the AFNs above. We see hints of these tendencies in the special issue articles about La Ruche che dit Oui! (Stephens and Barbier, this issue), on the CSA digital platforms in Barcelona (Espelt, 2020), Nested Markets in Italy (Osti and Carrosio, 2020) and on Vegan restaurants in Brazil (Niederle and Schubert, 2020).

Trust is based on social capital and alternative food networks create economic relations able to generate social capital. But to be able to trigger this beneficial mechanism, AFNs need formal institutions and stable participation. The more the relations are mediated, erratic or only based on the volunteering of members, the more the experiences are subjected to ups and downs putting into question the capacity to generate social capital in the long term. Setting up organisational forms and developing practices such as alternative auditing is the best guarantee to ensure that effective mechanisms of prosumption - such as 
those argued by Petrini - become the positive externalities of AFN experiences.

\section{Conclusions}

In this short introduction, we have put forward an integrated approach to thinking through the question of how the emergence and growth of prosumption influences the notion of labour in alternative agri-food networks. The dimensions and approaches through which we frame the role of prosumers should not be read as watertight compartments but as interlinked layers of analysis with respect to six elements.

1. The identities, values and goals that characterise prosumption and affect actors' motivations to co-produce;

2. The processes of acquisition (or even certification) of the adequate skills and competencies that a consumer needs in order to assume a productive role. We are interested in the extent of formalisation of these processes, the extent of their recognition in other domains of production (e.g., the market), and how they are linked with specific "prosumer repertoires of action".

3. The governance of work, in terms of how the work of the prosumer coordinates with that of market actors, or with different forms of community or family work. We are interested in the spectrum of organisation forms that range from self-organised work to hierarchical governance;

4. The professionalisation processes in prosumer work and the possible conversions of the cultural, economic and social capital of this productive work into other production domains;

5. The recognition and legitimisation of prosumer work, both in symbolic terms or real economic rewards;

6. The regulation of consumer-worker rights and the emergence of institutions that recognise and protect such hybrid actors. We are also interested in the different institutional environments that can foster productive action of consumers.

While these issues, and particularly their tendency to interact and overlap, complexify both the notions of productive work and consumption practices, we feel that this special issue is quite timely. The academic debate on the general concept of prosumption and labour has entered public discourse, particularly in Europe and in the United States with respect to the information technology and high-tech fields. However, we likewise note that there is little public discussion of these labour trends in the agriculture and food sectors. While we have begun to highlight this phenomenon in this special issue, we find ourselves in a situation where the more we look, the more questions we uncover. For example:

1. How might prosumers divert the socio-economic structures that lock small producers into a marginalised position in food systems? What are some of the consequences (intended and otherwise) of greater participation of consumers and citizens in food production?

2. Prosumption attempts to cut-out the 'middlemen', but what happens when these intermediaries try to come back in, particularly in terms of the standardisation of behaviours previously considered alternative, and with new forms of employment and division of labour in food systems?

3. What are the effects of prosumption on how spaces are being reconfigured, particularly in terms of the relationship between urban and rural areas, exchange and market spaces or the quality of the environment?

4. To what extent may prosumption provide responses to rural depopulation, 'counterurbanisation', the new peasantry, and new rural economies more generally?

We conclude this introduction with many open questions that aim to stimulate new research on a complex and poorly articulated topic in rural studies and the sociology of food and agriculture more broadly. Nonetheless, we do want to draw some key conclusions based on the articles presented in this special issue. First, the figure of "prosumer" can no longer be ignored in the academic debates around AFNs, particularly if we want to understand the real impact of the role of diverse and hybrid actors within them. Second, the traditional categories of enterprise, labour, property, transactions and finance are no longer sufficient for explaining the food system changes that we observe. Hybridisation of processes, institutions and actors seem to be increasingly important. Third, it is clear that we are dealing with economic and exchange processes where other values (such as trust, work, time, morals, etc.) serve as an exchange value instead of money. Finally if trust is based on social capital and AFNs create economic relations able to generate social capital, then this mechanism needs formalised rules, infrastructures and stable participation if these types of exchanges are to be institutionalised. For all these reasons we believe that there is ample space for developing a broad and articulated debate on the issue of prosumers in AFNs, capable of both understanding the empirical changes taking place and proposing new theoretical interpretations.

\section{Acknowledgements}

All authors contributed equally to the conceptual development of this article. The writing was coordinated by A. Podda and A. Loconto, but all authors contributed equal amounts of text to all sections of the article. L. Maestripieri created table 1.

\section{References}

Arcidiacono, D., 2013. Consumatori attivi: Scelte di acquisto e partecipazione per una nuova etica economica. FrancoAngeli, Milan.

Barbera, F., Dagnes, J., 2016. Building alternatives from the bottom-up: the case of alternative food networks. Agric. Agric. Sci. Procedia 8, 324-331.

Barbera, F., Dagnes, J., Di Monaco, R., 2020. Participation for what? Organizational roles, quality conventions and purchasing behaviors in solidarity purchasing groups. J. Rural Stud. 73, 243-251.

Barnard, C.I., 1938. The Functions of the Executive. Harvard University Press.

Bentham, Justin, Bowman, Andrew, de la Cuesta, Marta, Engelen, Ewald, Ertürk, Ismail, Folkman, Peter, Froud, Julie, Johal, Sukhdev, Law, John, Leaver, Adam, 2013. Manifesto for the foundational economy. University of Manchester, Manchester, UK. http://hummedia.manchester.ac.uk/institutes/cresc/workingpapers/wp131.pdf. (Accessed 24 December 2020).

Bruns, A., 2008. Blogs, Wikipedia, Second Life, and beyond: from Production to Produce, Peter Lang, New York.

Carrera, L., 2009. I Gruppi di Acquisto Solidale. Una proposta solida nella società liquida. Partecipazione e Conflitto 95-122.

de Certeau, M., 2011. The Practice of Everyday Life. University of California Press, Berkeley and Los Angeles, California.

Dujarier, M.-A., 2009. Quand consommer, c'est travailler. Idées économiques et sociales $158,6-12$.

Dusi, D., 2018. Beyond prosumer capitalism: retaining the original understanding of prosumption. Curr. Sociol. 66, 663-681.

Espelt, R., 2020. Agroecology prosumption: the role of CSA networks. J. Rural Stud. 79, 269-275.

FAO, 2020. Cities and Local Governments at the Forefront in Building Inclusive and Resilient Food Systems: Key Results from the FAO Survey "Urban Food Systems and COVID-19. Food and Agriculture Organization of the United Nations, Rome.

Fuchs, V.R., Leveson, I.F., 1968. The Service Economy. National Bureau of Economic Research, New York.

Gibson-Graham, J.K., 2008. Diverse economies: performative practices for 'other worlds'. Prog. Hum. Geogr. 32, 613-632.

Glucksmann, M., 2009. Formations, connections and divisions of labour. Sociology 43, 878-895.

Glucksmann, M., 2016. Completing and complementing: the work of consumers in the division of labour. Sociology 50, 878-895.

Goodman, D., DuPuis, E.M., Goodman, M.K., 2012. Alternative Food Networks Knowledge, Practice, and Politics. Routledge, Abingdon, Oxon ; New York.

Grasseni, C., 2013. Beyond Alternative Food Networks: Italy's Solidarity Purchase Groups. Bloomsbury Publishing.

Hatanaka, M., 2020. Beyond consuming ethically? Food citizens, governance, and sustainability. J. Rural Stud. 77, 55-62.

Hinrichs, C.C., 2000. Embeddedness and local food systems: notes on two types of direct agricultural market. J. Rural Stud. 16, 295-303.

Johnston, J., 2008. The citizen-consumer hybrid: ideological tensions and the case of Whole Foods Market. Theor. Soc. 37, 229-270.

Langeard, E., Eiglier, P., 1997. Servuction. Le marketing des services. Delmas et Cie, Paris. 
Maestripieri, L., 2018. Are Solidarity Purchasing Groups a Social Innovation? A Study Inspired by Social Forces.

Maestripieri, L., 2019. Creating alternative economic spaces. The socially innovative practices of solidarity purchasing groups. In: Nicholls, A., Ziegler, R. (Eds.), Creating Economic Space for Social Innovation. Oxford University Press, Oxford.

Marechal, G., 2020. Une tentative d'interprétation de la demande adressée aux circuits courts en lien avec la crise COVID 19 : la forte demande va-t-elle perdurer ? TERRALIM, Reseau mixte technique alimentation locale, Montpellier, FR.

Marsden, T., Flynn, A., Harrison, M., 2000. Consuming Interests: the Social Provision of Foods. UCL Press, London.

Niederle, P., Schubert, M.N., 2020. HOW does veganism contribute to shape sustainable food systems? Practices, meanings and identities of vegan restaurants in Porto Alegre, Brazil. J. Rural Stud. 78, 304-313.

Osti, G., Carrosio, G., 2020. Nested markets in marginal areas: weak prosumers and strong food chains. J. Rural Stud. 76, 305-313.

Ostrom, M., De Master, K., Noe, E., Schermer, M., 2017. Values-based food chains from transatlantic perspective: exploring a middle tier of agri-food system development. Int. J. Sociol. Agric. Food 24, 1-14.

Pellicer-Sifres, V., Belda-Miquel, S., López-Fogués, A., Boni Aristizábal, A., 2017. Grassroots social innovation for human development: an analysis of alternative food networks in the city of Valencia (Spain). J. Human Dev. Capabilities 18, 258-274. Petrini, C., 2003. Slow Food : the Case for Taste. Columbia University Press, New York

Polanyi, K., 1957. The Great Transformation, 1st Beacon paperback ed. Beacon Press, Boston.

Renting, H., Marsden, T.K., Banks, J., 2003. Understanding alternative food networks: exploring the role of short food supply chains in rural development. Environ. Plann. 35, 393-411.

Renting, H., Schermer, M., Rossi, A., 2012. Building food democracy: exploring civic food networks and newly emerging forms of food citizenship. Int. J. Sociol. Agric Food 19, 289-307.

Ritzer, G., 2014. Prosumption: evolution, revolution, or eternal return of the same? J. Consum. Cult. 14, 3-24.

Stolle, D., Hooghe, M., Micheletti, M., 2005. Politics in the supermarket: political consumerism as a form of political participation. Int. Polit. Sci. Rev. 26, 245-269.

Toffler, A., 1970. Future Shock. Random House, New York.
Watson, M., Shove, E., 2008. Product, competence, project and practice:DIY and the dynamics of craft consumption. J. Consum. Cult. 8, 69-89.

Willis, M.M., Schor, J.B., 2012. Does changing a light bulb lead to changing the world? Political action and the conscious consumer. Ann. Am. Acad. Polit. Soc. Sci. 644, $160-190$.

Winter, M., 2003. Embeddedness, the new food economy and defensive localism. J. Rural Stud. 19, 23-32.

Zamagni, S., 2003. L'impresa socialmente responsabile nell'epoca della globalizzazione. Politeia 29, 28-42.

Antonello Podda ${ }^{a}$, Allison Marie Loconto ${ }^{\text {b, }}$, Davide Arcidiacono ${ }^{c}$, Lara Maestriprieti ${ }^{\mathrm{d}, \mathrm{e}}$

a Dipartimento di Scienze Politiche e Sociali, Università degli Studi di Cagliari, via S.Ignazio 78, 09123, Cagliari, Italy

${ }^{\mathrm{b}}$ Institut national de recherche pour l'agriculture, l'alimentation et l'environnement (INRAE), Laboratoire Interdisciplinaire Sciences Innovations et Sociétés (LISIS), Université Gustave Eiffel, 5 blvd. Descartes, 77454, Marne-la-Vallée Cedex 02, France

${ }^{\mathrm{c}}$ Dipartimento di Scienze Politiche e Sociali-Università degli Studi di Catania, Via Vittorio Emanuele 8, 20148, Catania, Italy

d Dastu/Politecnico di Milano, via Bonardi 33, 20133, Milano, Italy e IGOP/Universitat Autònoma de Barcelona, Campus Bellaterra (Cerdanyola del Valles), 08193, Spain

"Corresponding author

E-mail addresses: podda@unica.it (A. Podda), allison-marie. loconto@inrae.fr (A.M. Loconto), dlarcid@unict.it (D. Arcidiacono), lara.maestripieri@polimi.it (L. Maestriprieti). 